\title{
FOXN1 deficient nude severe combined immunodeficiency
}

\author{
Ioanna A. Rota ${ }^{1}$ and Fatima Dhalla $a^{1,2^{*}}$
}

\begin{abstract}
Nude severe combined immunodeficiency is a rare inherited disease caused by autosomal recessive loss-of-function mutations in FOXN1. This gene encodes a transcription factor essential for the development of the thymus, the primary lymphoid organ that supports T-cell development and selection. To date nine cases have been reported presenting with the clinical triad of absent thymus resulting in severe T-cell immunodeficiency, congenital alopecia universalis and nail dystrophy. Diagnosis relies on testing for FOXN1 mutations, which allows genetic counselling and guides therapeutic management. Options for treating the underlying immune deficiency include HLA-matched genoidentical haematopoietic cell transplantation containing mature donor T-cells or thymus tissue transplantation. Experience from other severe combined immune deficiency syndromes suggests that early diagnosis, supportive care and definitive management result in better patient outcomes. Without these the prognosis is poor due to early-onset life threatening infections.
\end{abstract}

Keywords: Immunodeficiency, Thymus, T-cell, Alopecia, Nail dystrophy, FOXN1

\section{Background}

Nude severe combined immunodeficiency (SCID) is a rare inherited syndrome caused by a functional deficiency of FOXN1, a transcription factor essential for the development and function of thymic epithelial cells (TECs) [1-3].

The thymus is the primary lymphoid organ responsible for the development of $\mathrm{T}$ lymphocytes from bone marrow derived haematopoietic precursors [4]. The unique threedimensional structure of TECs forms the appropriate physiological microenvironment for the generation T-cells able to effect immune responses against foreign pathogens whilst being tolerant to the body's own proteins (designated "self") [5]. The study of loss-of-function mutations in Foxn1 in animal models has shown its critical importance in TEC differentiation, homeostatic maintenance and T-cell lymphopoiesis [3, 6-9].

Absent thymus (athymia), alopecia universalis (AU) and nail dystrophy were first noted in 1966 in a spontaneously occurring phenotype in the so-called nude mouse [9-11]. The molecular cause was identified in 1994 to be due to an autosomal recessive deletional mutation in the

\footnotetext{
* Correspondence: fatima.dhalla@paediatrics.ox.ac.uk

'Developmental Immunology Group, Department of Paediatrics, University of Oxford, Oxford, UK

${ }^{2}$ Department of Clinical Immunology, Oxford University Hospitals, Oxford, UK
}

whn gene, later renamed Foxn1 $[7,12]$. Thirty years after its first description in mice, the human counterpart of the nude phenotype was reported in two sisters presenting with early-onset severe immunodeficiency associated with congenital alopecia and nail dystrophy $[1,2]$.

FOXN1 is required for the development of epithelial cells in the thymus, the skin, hair and nails [7, 13-19]. As the developmental defect of TECs results in a lack of regular T-cell development and selection, FOXN1 deficiency has been classified as a rare form of severe combined immunodeficiency (SCID) with absent or low Tcells (i.e. a $\mathrm{T}^{- \text {llow }} \mathrm{B}^{+} \mathrm{NK}^{+} \mathrm{SCID}$ ). SCID syndromes are an aetiologically heterogeneous group of genetic disorders, defined by defects in T-cell development and function and a variable impact on the development of B- and NKcells [20]. Consequently patients are unable to produce protective immune responses and present in early infancy with life-threatening infections [20]. Nude SCID is an example of a SCID syndrome that is not due to mutation of a gene expressed in hematopoietic cells but rather constitutes an abnormality of the thymic stromal cell compartment, namely TECs, essential for normal T-cell development [21]. As with other SCIDs, early diagnosis and management is critical in order to prevent accumulation of end-organ damage due to severe infections [22]. 


\section{Review}

\section{Disease name/synonyms}

Nude SCID [2, 23] is also known as FOXN1 deficiency [23], alymphoid cystic thymic dysgenesis (ORPHA169095)

[24], severe T-cell immunodeficiency, congenital alopecia, nail dystrophy syndrome (MIM601705) [1] and Winged helix deficiency [2].

\section{Epidemiology}

Nude SCID is very rare with an estimated incidence of $<1 / 1,000,000$. Only nine cases have been reported in the literature to date. Six patients originated from Acerno in southern Italy; all had the same homozygous founder mutation (R255X) carried by $6.52 \%$ of the village's inhabitants [25]. An identical mutation was later identified in a Portuguese child born to consanguineous parents [23]. Two additional mutations have been identified in single patients of mixed French/African (R320W) and consanguineous Lebanese origin (S188fs) $[23,26]$.

\section{Clinical description}

The human nude SCID phenotype is characterised by the clinical triad of athymia and resultant SCID, congenital AU and nail dystrophy (Table 1) [1, 23, 25-27].

All reported patients presented in the first months of life with severe, recurrent, life-threatening infections [1, 23, 25] reflecting their severely impaired T-cell-mediated immune response to viral, fungal and opportunistic infections as well as live vaccines [1, 23, 28, 29]. Although B-cells are typically present in normal numbers, antibody production is compromised in the absence of T-cell help $[1,23,29]$ rendering patients susceptible to infections with encapsulated bacteria $[1,23,29,30]$. Patients with nude SCID may have features of Omenn Syndrome (OS) [1, 23, 26], an inflammatory condition caused by expansions auto-reactive T-cells in the setting of SCID and characterised by erythroderma, hepatosplenomegaly, lymphadenopathy, diarrhoea and failure-to-thrive [31]. A detailed description of the immunological phenotype can be found in Tables 1 and 2 and in the section on diagnosis.

Dermatological features include congenital alopecia affecting the scalp, eyebrows and eyelashes, and nail dystrophy. The latter most frequently features proximal arciform leukonychia and koilonychia, although canaliform dystrophy and Beau's lines have been noted [32]. Nail dystrophy has also been found in heterozygous carriers of FOXN1 mutations [32].

CNS defects have only been described in two fetuses from a single kindred in the highly consanguineous village of Acerno. One displayed anencephaly and spina bifida [13], the other had milder abnormalities including an enlarged interhemispheric fissure and absence of the cavum septi pellucidi and corpus callosum [14].

\section{Aetiology}

Following the fist description of nude SCID [1], linkage analysis and sequencing of the FOXN1 gene in the two index cases, revealed a homozygous nonsense mutation leading to a premature stop codon at amino acid 255 (R255X) [2]. Two additional autosomal recessive FOXN1 mutations (R320W and S188fs) have since been described $[23,26]$.

The forkhead box N1 (FOXN1) protein is a transcription factor expressed in epithelial cells of the thymus, skin, hair follicles and nail bed $[13,15,33]$. The precise molecular mechanisms of FOXN1 function are not completely understood. It is thought to be activated by phosphorylation, translocate to the nucleus [34-36], bind DNA through its forkhead domain (Fig. 1) [12, 37, 38], and promote the transcription of genes that control the development of epithelial cells [3]. Experimental models have demonstrated that the $\mathrm{N}$-terminal aspect of FOXN1 is critical for murine TEC differentiation and the $\mathrm{C}$-terminus is required for transcriptional activation of target genes [37, 39, 40].

The reported human FOXN1 mutations are located in different domains of the molecule (Fig. 1), however all are thought to result in loss of function. The R255X and S188fs mutations, located in the N-terminus, both cause a premature stop codon predicted to result in non-sense mediated decay of the mRNA $[2,26]$. The R320W mutation lies in the evolutionary conserved forkhead domain and is thought to impair the ability of the mutated protein to bind DNA and thus regulate the transcription of target genes [23].

T-cells are derived from blood-borne haematopoietic precursors that seed the thymus where they develop within a meshwork of stromal cells built primarily by TECs [41]. TECs secrete, in a FOXN1 dependent manner, several chemokines, CCL25, CCL21, CXCL12, that are required for attracting haematopoietic progenitors to the developing thymus [42]. These progenitors subsequently commit to a T-cell fate with the support of TEC-derived molecules such as the notch ligand DLL4, which is also transcriptionally regulated by FOXN1 [43]. Following an initial round of expansion, developing T-cells are subjected to selection processes, termed "positive" and "negative" selection, which are driven by recognition of MHC-self antigen complexes presented on the surface of TECs $[5,41]$. This interaction leads to the selection of a Tcell repertoire that is self-tolerant but able to respond to foreign antigens [5, 41]. The developing T-cells then undergo a final maturation process before exiting to the peripheral circulation as single positive CD4 or CD8 naïve T-cells $[5,41]$. FOXN1 is a core transcriptional regulator essential for TEC differentiation, maintenance and function $[3,44,45]$. It is now known to control the expression of hundreds of genes in TECs that support intrathymic T-cell 


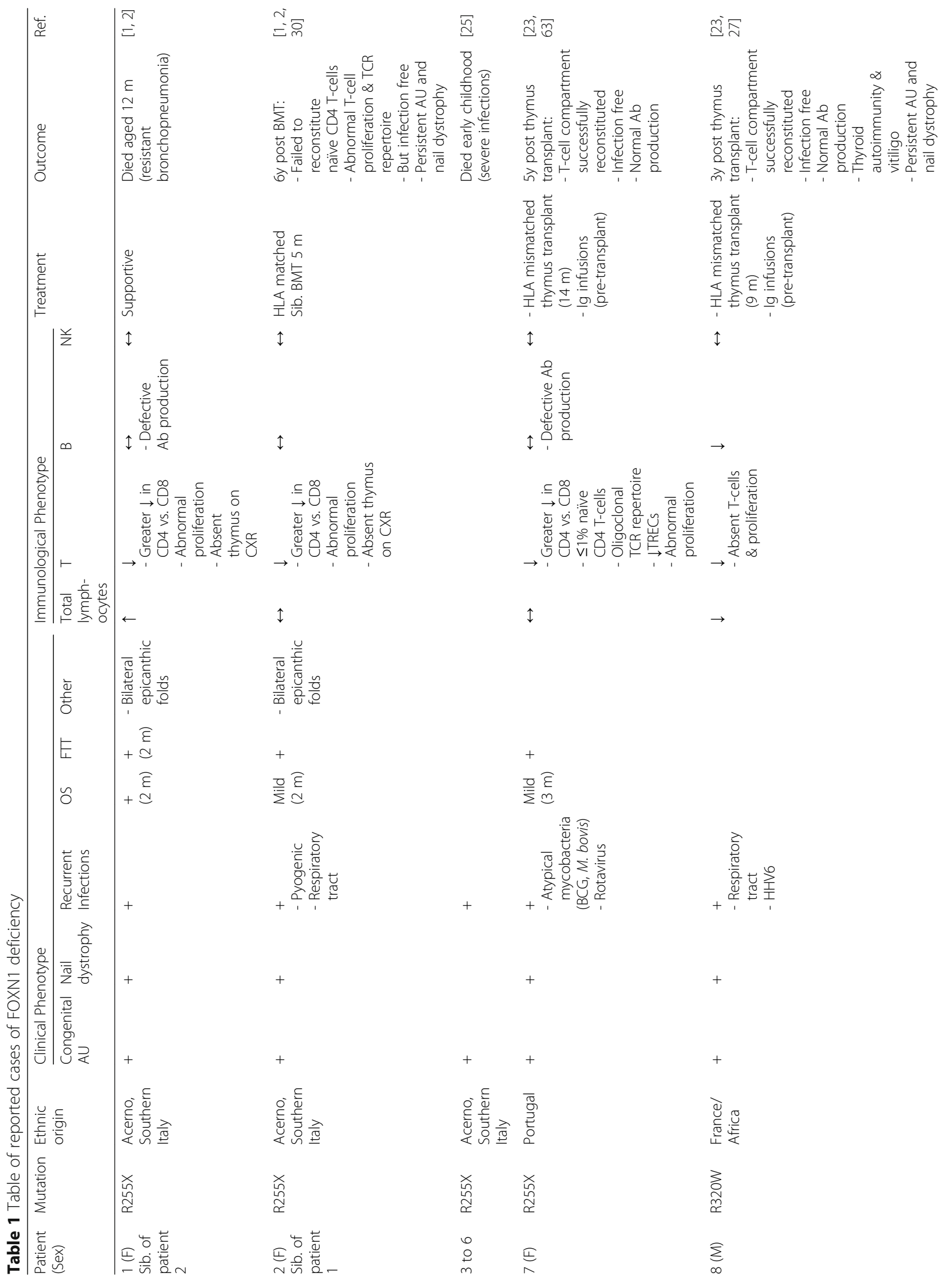




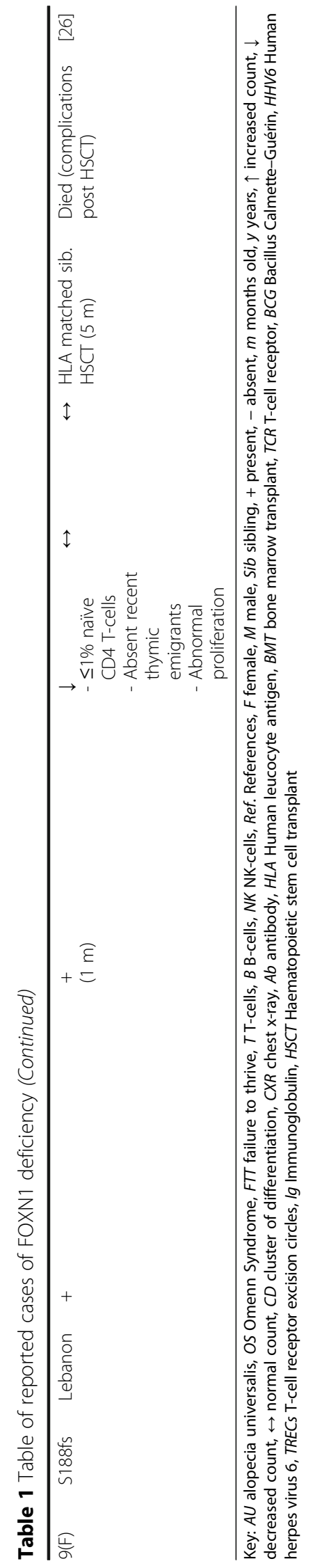


Table 2 Table of suggested diagnostic tests and investigations with expected findings

\begin{tabular}{|c|c|c|c|}
\hline Category & Test(s) & Expected findings & Ref. \\
\hline Genetic & $\begin{array}{l}\text { - FOXN1 sequencing } \\
\text { - PCR for previously reported FOXN1 mutations }\end{array}$ & $\begin{array}{l}\text { - Homozygous FOXN1 mutation } \\
\text { - Previously reported mutations: R255X, R320W, S188fs }\end{array}$ & {$[2,23,25,26]$} \\
\hline \multirow[t]{3}{*}{ Basic Immunology } & Differential white cell count & $\begin{array}{l}\text { - Total lymphocyte count } \downarrow / \leftrightarrow / \uparrow \\
\text { - } \uparrow \text { Eosinophils in Omenn syndrome }\end{array}$ & {$[1,23]$} \\
\hline & Lymphocyte subpopulations & $\begin{array}{l}\text { - } \downarrow \text { T-cell count (greater reduction in CD4+ T-cells Vs. CD8+) } \\
\text { - ↔B-cell count (although } \downarrow \text { in } 1 \text { reported case) } \\
\text { - ↔/ NK-cell count }\end{array}$ & {$[1,23,26]$} \\
\hline & Serum Immunoglobulins & $\begin{array}{l}\leftrightarrow / \downarrow \\
-\uparrow \operatorname{lgE} \text { in Omenn syndrome }\end{array}$ & [23] \\
\hline \multirow{6}{*}{$\begin{array}{l}\text { Specialised } \\
\text { Immunology }\end{array}$} & TRECS & Severely $\downarrow$ or absent & [23] \\
\hline & Recent thymic emigrants (CD4 + CD31 + CD45RA+) & Severely $\downarrow$ or absent & [26] \\
\hline & $\begin{array}{l}\text { Markers of T-cell memory (CD45RA \& CD } 45 R O) \text { and } \\
\text { activation (HLA-DR) }\end{array}$ & $\begin{array}{l}\text { - Severely } \downarrow \text { naïve (CD45RA+) T-cells } \\
\text { - } \uparrow \text { memory (CD45RO+) T-cells } \\
\text { - } \uparrow \text { HLA-DR+ in Omenn syndrome }\end{array}$ & {$[23,26,30]$} \\
\hline & T-cell proliferation to mitogens & $\begin{array}{l}\text { - } \downarrow \text { in response to anti-CD3 \&/or PHA } \\
\text { - May be normal in response to PMA and ionomycin }\end{array}$ & {$[1,23,26]$} \\
\hline & $\begin{array}{l}\text { T-cell receptor repertoire via flow cytometry or } \\
\text { spectratyping }\end{array}$ & Oligoclonal & {$[23,26]$} \\
\hline & $\begin{array}{l}\text { Specific antibodies to exposure and immunisation } \\
\text { antigens }\end{array}$ & $\downarrow$ & [1] \\
\hline Thoracic imaging & Chest x-ray/ultrasound scan/MRI & $\begin{array}{l}\text { - Absent thymus } \\
\text { - May show evidence of respiratory tract infection }\end{array}$ & [1] \\
\hline
\end{tabular}

Key: Ref. References, $P C R$ polymerase chain reaction, $\uparrow$ increased, $\downarrow$ decreased, $\leftrightarrow$ normal, $C D$ cluster of differentiation, $l g$ immunoglobulin, TRECs T-cell receptor excision circles, HLA Human leucocyte antigen, PHA Phytohaemagglutinin, PMA phorbol myristate acetate, MRI magnetic resonance imaging

development [3]. In addition to CCL25 [42], CXCL12 [3], and $D L L 4$ [43], FOXN1 positively regulates the expression of a number of genes involved in antigen processing and presentation [3]. Lack of functional FOXN1 in TECs therefore disrupts normal thymic organogenesis and the ability to support T-cell lineage commitment, development and selection $[8,10,11,15]$.

In the skin and its appendages FOXN1 is expressed in epithelial cells that have stopped proliferating and are in the process of terminal differentiation [15, 33]. Studies in mouse keratinocytes suggest that FOXN1 controls the expression of protein kinase $\mathrm{B}$ and $\mathrm{C}$, molecules that are involved in cell survival, metabolism and cell cycle progression [46, 47]. As a consequence, loss-of-function mutations disrupt the balance between normal growth and differentiation of these cells [15, 17-19]. Humans and mice with FOXN1 deficiency have numerically normal hair follicles that give rise to hairs with an abnormal

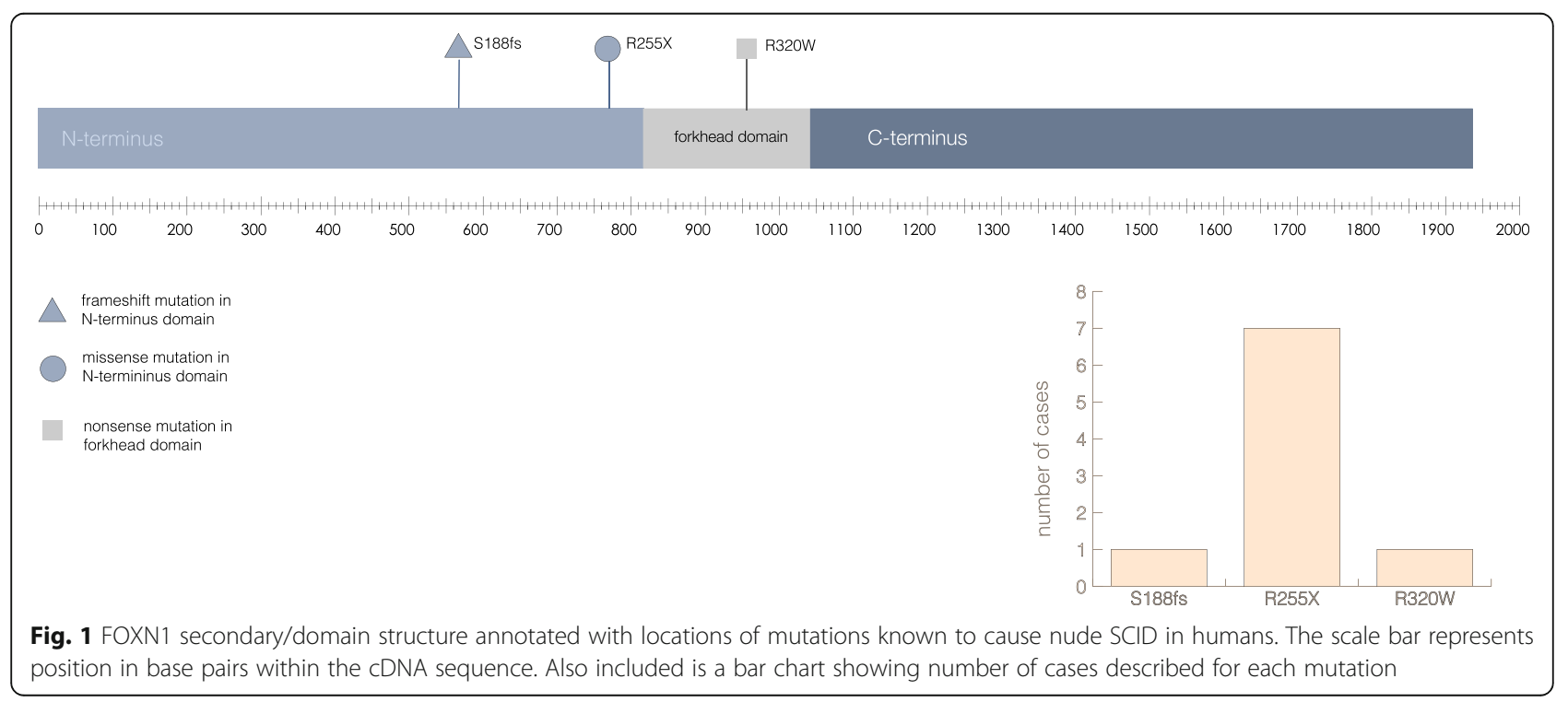


shaft causing them to curl and break off at the level of the skin surface leading to alopecia $[9,48]$.

The role of FOXN1 in CNS development is not confirmed. Neurodevelopmental defects have not been reported in mouse models and, given that the only two fetuses with neurological abnormalities came from the same family within a closed population [13, 14], it is possible that another genetic aetiology was responsible for their neurological features, however this has not been formally investigated.

\section{Diagnosis}

Nude SCID due to FOXN1 deficiency should be suspected in infants presenting with clinical and/or laboratory evidence of immunodeficiency associated with congenital AU and nail dystrophy [1, 2, 23, 25, 26, 49].

Population-based newborn screening (NBS) programmes for SCID have been introduced in several countries [50-52]. Polymerase chain reaction (PCR) on DNA extracted from Guthrie card blood spots is used to quantify circularised DNA by-products generated during TCR formation in the thymus, called T-cell receptor excision circles (TRECs) [53, 54]. Deficient levels of TRECs identified during NBS indicate T-cell deficiency requiring further investigation. It is predictable that FOXN1 deficiency will be detectable on the basis of absent/low TRECs although, as yet, there are no reports in the literature of patients identified via NBS. Indeed, Infants with FOXN1 deficiency have been shown to have very low TREC levels [23] and lack other markers of thymic T-cell output [26]. In addition, NBS has been able to identify patients with severe T-cell deficiency due to other primary thymic defects including DiGeorge (DGS) and CHARGE syndrome [52, 55].

Infants with suspected nude SCID should be immediately referred to a specialist centre experienced in and equipped for specialised immunological tests and management of severe immunodeficiencies [28]. This is important as early diagnosis and treatment have been shown to greatly impact upon outcomes, including survival, in children with SCIDs [56]. Diagnostic tests and further investigations are detailed in the text below and summarised along with expected findings in Table 2.

Definitive diagnosis relies on testing for FOXN1 mutations [2] and is essential in order to guide patient management and genetic counselling [23,26]. If the clinical suspicion is high this may be achieved by a targeted approach using single gene Sanger sequencing or screening for described mutations [2, 23, 25, 26]. Alternatively, next generation sequencing techniques may be used including targeted sequencing panels, which are increasingly available for the molecular diagnosis of patients presenting with primary immune deficiency [57-61].
Basic immunological assessment should include enumeration of total lymphocytes, lymphocyte subpopulations (T-, B-, and NK-cells), and serum immunoglobulins [22, 62]. Results should be interpreted alongside agespecific reference ranges. Total lymphocyte count may be normal, decreased or increased [1, 23]. However, patients have universally shown low T-cell counts $[1,23,26]$, with CD4+ T-cells more severely affected than CD8 + $[1,23]$. NK- and B-cells are expected to be present, although the latter are poorly functional in terms of specific antibody production $[1,23,26]$.

More specialised investigations include analysis of T-cell subpopulations and receptor repertoire, markers of thymic T-cell output, and T- and B-cell function [22, 62]. Patients with FOXN1 deficiency have been shown to lack evidence of efficient thymic T-cell output with increased double negative (CD4-CD8-) T-cells in the peripheral blood [23, 63], and severe reductions in TRECs [23], CD31+ recent thymic emigrants [26], and CD45RA+ naïve CD4+ T-cells resulting in skewing towards a CD45RO+ memory phenotype [23, 26, 30]. Their T-cells show reduced in vitro proliferation and an oligoclonal TCR repertoire $[1,23,26]$. Those presenting with OS may have eosinophilia, elevated serum IgE and presence of activated (HLADR+), oligoclonal T-cells [22, 62].

Thoracic imaging should be performed to document thymic hypo-/aplasia $[1,22]$. Patients should be actively screened for viral, fungal and bacterial infections via microbiological examination of respiratory secretions and stools, and imaging; blood should also be tested for the presence of Epstein Barr (EBV) and cytomegalovirus (CMV) nucleic acid [64]. It is important to note that serological tests are unreliable due to poor B-cell function.

\section{Differential diagnosis}

Although the triad of congenital AU, nail dystrophy and athymia is highly indicative of FOXN1 deficient nude SCID, there are several differential diagnoses that warrant consideration (Table 3). These include alternative causes of SCID, combined immune deficiency (CID) and OS that have a similar immunophenotype (i.e. $\mathrm{T}^{-/ \text {low }} \mathrm{B}^{+} \mathrm{NK}^{+}$), other primary thymic defects [49], and dyskeratosis congenita (DC). However, in DC differentiating clinical features such as abnormal skin pigmentation and oral leucoplakia are often present $[48,49,65]$.

\section{Genetic counselling and antenatal diagnosis}

Once a molecular diagnosis is ascertained, parental carrier status should be assessed. In highly consanguineous populations, testing for carrier status could also be extended to the wider family [25]. As an autosomal recessive disease, the risk of disease transmission in future pregnancies is 1 in 4 if both parents are carriers. Antenatal 


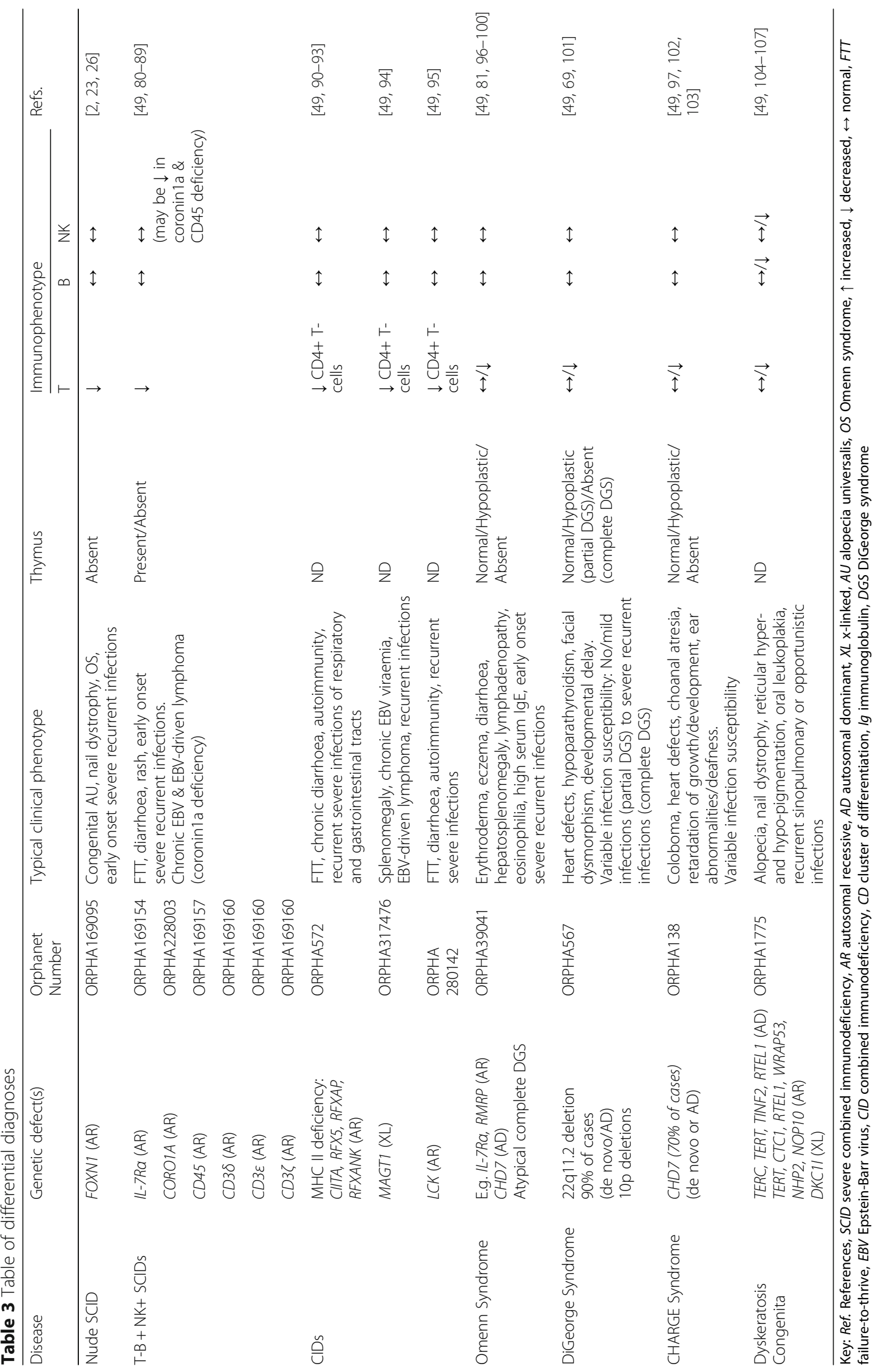


diagnosis can be achieved via chorionic villus sampling or amniocentesis $[25,66]$. Where parents decide to continue with an affected pregnancy, this will allow preparation for immediate supportive and early definitive management of the underlying immune deficiency in a specialist centre [56].

\section{Management}

Infants with suspected nude SCID require prompt referral to a specialist centre experienced in management of SCID. Management of such cases involves supportive care, which aims to optimise the patient's clinical condition before timely institution of definitive treatment to correct the underlying immune deficiency [64].

Prophylaxis and early treatment of infections is of upmost importance and has been shown to improve outcomes in other forms of SCIDs [28, 67]. This involves isolation in a laminar flow room, prophylaxis against Pneumocystis jiroveci pneumonia, fungal and viral infections, and immunoglobulin replacement $[28,62,64,67]$. Live vaccines are contraindicated and anti-mycobacterial treatment should be initiated in those immunised with BCG before an immunodeficiency was suspected $[28,62,64]$. If blood products are required these should be CMV negative, irradiated and depleted of leucocytes $[28,62,64,68]$. In the setting of OS careful immunosuppression may be required [64].

Of the four patients that have received treatments aimed at correcting the underlying immune deficiency, two received HLA-matched sibling/genoidentical haematopoietic cell transplants (HCT) at the age of 5 months $[1,26,30]$, and two had thymic transplants at 9 and 14 months of age [23].

One of the HCT recipients died following posttransplant complications [26], whereas the other was alive and infection-free when assessed 6 years later likely due to the presence of mature donor T-cells with proliferative capacity present in the bone marrow graft [30,69]. Experience from complete DGS suggests that HCT is unlikely to result in high quality immune reconstitution in the context of an underlying thymic stromal cell defect [30, 69]. However, patients treated with HLA-matched sibling HCT have better outcomes compared to those treated with matched unrelated transplants [70]. In a multicentre retrospective study on the outcomes of 17 patients with complete DGS treated with HCT overall survival was $41 \%$ after 4-11.5 years of follow-up. However, in the subgroup that received transplants from HLAmatched sibling donors overall survival was significantly better at over $60 \%$ [70]. There are several possible reasons for this: for example, the need for serotherapy using antibodies directed against $\mathrm{T}$-cells in patients treated with matched unrelated transplants is likely to preclude the survival of mature donor T-cells present in the graft necessary to provide cellular immunity in the absence of a functional thymus. In addition, it has been noted that graft versus host disease is particularly severe in patients with athymia [70].

Given that FOXN1 is expressed in TECs and not haematopoietic cells, establishing a functional thymic stromal environment is expected to provide more complete and long-lasting immune reconstitution [23, 26]. This can be achieved via transplantation into the quadriceps muscle of non-HLA matched thymic tissue obtained from infants undergoing corrective cardiac surgery [71]. This highly specialist treatment is currently limited to two centres worldwide [69]. Reconstitution of successful T-cell lymphopoiesis was achieved in both FOXN1 deficient cases treated with thymic transplantation as evidenced by T-cell count, and the presence of TREC positive naive CD4+ T-cells, and CD31+ recent thymic emigrants in the peripheral blood. The newly generated T-cells proliferate normally, display a diverse TCR repertoire, and are able to support the production of specific antibodies directed against T-cell dependent antigens [23, 63]. Both patients cleared infections present pre-transplantation and remained infection-free 3-5 years later. However, one patient developed autoimmune hypothyroidism and vitiligo $[23,27]$. Precedence for the use of thymic transplantation in patients with FOXN1 deficiency comes from experience in complete DGS, where patients also have an intrinsic thymic stromal defect that precludes normal T-cell development $[69,70,72]$. Outcomes after thymic transplantation for complete DGS are at least as good as HCT with respect to overall survival (over $70 \%$ ), and the quality of immune reconstitution is superior [69-73]. T-cell reconstitution after thymic transplantation however takes several months and autoimmune diseases are observed in a third of patients principally affecting the thyroid [69, 71, 73].

In summary, from the available evidence, the following recommendations can be made in order to aid in the selection of the most appropriate definitive treatment for individual patients with nude SCID. HCT containing mature donor T-cells should only be offered to patients with an HLA-matched genoidentical sibling donor; this treatment approach may be particularly important in situations where thymic transplantation is not readily available or in the context of pre-existing systemic viral infection, where rapid recovery of T-cell mediated immunity is required [69, 70, 74]. Alternatively, thymic transplantation could be used, without the need for HLA-matching, provided that it is accessible in a timely manner and that rapid T-cell recovery is not required $[74,75]$. If an HLA-matched sibling donor is not available for HCT, however, evidence from DGS suggests that outcomes are likely to be superior with thymic transplantation [70]. 
Important developments within the field of regenerative medicine may provide strategies for the definitive management of thymic stromal cell defects in the future. Induced pluripotent stem cells (iPSCs) have been used to successfully generate thymic organoids capable of supporting in vivo T-cell development in mouse models, including nude mice [76-79]. Although HLA-matching is not essential for transplantation of thymic tissue [75], this technology could be combined with gene therapy in order to allow the transplantation of autologous thymic organoids generated from gene corrected iPSCs.

\section{Prognosis}

Early diagnosis, supportive care and definitive treatment results in improved outcomes for patients with SCID [56]. All reported nude SCID patients in whom definitive treatments could not be established succumbed to infections very early in childhood $[1,25]$.

\section{Unresolved questions}

It remains unclear whether any relevant genotypephenotype correlation exists that could explain the variation in immunological findings observed. The patient with a missense mutation in the forkhead domain (R320W) demonstrated complete absence of circulating T-cells [23], whereas patients with mutations in the $\mathrm{N}$ terminus that lead to premature stop codons (R255X and S188fs) [2, 23, 26], have a less severe immunological phenotype and retain a limited number of peripheral Tcells. A possible explanation for the milder phenotype in the latter could be re-initiation of transcription from an alternative start codon downstream of the mutations. Indeed two such possible alternative start codons exist and, if formed, the resulting transcripts would have intact DNA binding and transcriptional activation domains and therefore could translate into partially functional $\mathrm{N}$ terminally truncated proteins. In contrast, the R320W mutation is thought to impair binding of the mutated FOXN1 protein to DNA and thus abrogate its ability to regulate the transcription of target genes [23]. However, with such few cases reported and in the absence of experimental evidence to confirm or refute the above, it is difficult to draw firm conclusions concerning possible genotype-phenotype correlations and their mechanisms.

\section{Conclusions}

Nude SCID caused by FOXN1 deficiency should be suspected in infants presenting with severe T-cell immunodeficiency associated with congenital $A U$ and nail dystrophy. Prompt diagnosis, supportive care and referral to a specialist centre for definitive treatment are of paramount importance in order to ensure best possible outcomes [56].

\section{Abbreviations}

Ab: Antibody; AU: Alopecia Universalis; BCG: Bacillus Calmette-Guérin; BMT: Bone marrow transplant; CD: Cluster of differentiation; CHARGE: Coloboma, heart defects, atresia of the choanae, retardation of growth/development, ear abnormalities/deafness; CID: Combined immunodeficiency; CNS: Central nervous system; CXR: Chest x-ray; DGS: DiGeorge syndrome; DLL4: Delta-like ligand 4; FOXN1: Forkhead box N1; FTT: Failure-to-thrive; HCT: Haematopoietic cell transplant; HLA: Human leucocyte antigen; HSCT: Haematopoietic stem cell transplant; Ig: Immunoglobulin; MRI: Magnetic resonance imaging; NBS: Newborn screening; NK: Natural killer; OS: Omenn syndrome; PCR: Polymerase chain reaction; PHA: Phytohaemagglutinin; PKC: protein kinase C; PMA: Phorbol myristate acetate; SCID: Severe Combined Immunodeficiency; Sib: Sibling; TCR: T-cell receptor; TECs: Thymic epithelial cells; TRECs: T-cell receptor excision circles

\section{Acknowledgements}

We would like to thank Georg Hollander for reading the manuscript and providing expert opinion.

\section{Funding}

FD is in receipt of a Wellcome Trust Research Training Fellowship.

\section{Availability of data and material}

Not applicable.

\section{Authors' contributions}

FD supervised the writing of the manuscript, prepared the tables and wrote the sections on disease synonyms, epidemiology, diagnosis, differential diagnosis, genetic counselling, management, prognosis and conclusions; IR wrote the abstract, introduction and sections on clinical description, aetiology and unresolved questions. Both authors read and approved the final manuscript.

\section{Competing interests}

The authors declare that they have no competing interests.

\section{Consent for publication}

Not applicable.

Ethics approval and consent to participate

Not applicable.

Received: 6 October 2016 Accepted: 15 December 2016

Published online: 11 January 2017

\section{References}

1. Pignata C, Fiore M, Guzzetta V, Castaldo A, Sebastio G, Porta F, et al. Congenital Alopecia and nail dystrophy associated with severe functional T-cell immunodeficiency in two sibs. Am J Med Genet. 1996;65(2):167-70.

2. Frank J, Pignata C, Panteleyev AA, Prowse DM, Baden $H$, Weiner $L$, et al. Exposing the human nude phenotype. Nature. 1999;398(6727):473-4.

3. Zuklys S, Handel A, Zhanybekova S, Govani F, Keller M, Maio S, et al. Foxn1 regulates key target genes essential for T cell development in postnatal thymic epithelial cells. Nat. Immunol. 2016;17:1206-15. doi:10.1038/ni.3537.

4. Miller JF. Immunological function of the thymus. Lancet (London, England). 1961;2(7205):748-9.

5. Anderson G, Takahama Y. Thymic epithelial cells: working class heroes for $T$ cell development and repertoire selection. Trends Immunol. 2012;33(6):256-63.

6. Schorpp M, Hofmann M, Dear TN, Boehm T. Characterization of mouse and human nude genes. Immunogenetics. 1997:46(6):509-15.

7. Nehls M, Pfeifer D, Schorpp M, Hedrich H, Boehm T. New member of the winged-helix protein family disrupted in mouse and rat nude mutations. Nature. 1994;372(6501):103-7.

8. Vaidya HJ, Briones Leon A, Blackburn CC. FOXN1 in thymus organogenesis and development. Eur J Immunol. 2016;46(8):1826-37.

9. Flanagan SP. 'Nude', a new hairless gene with pleiotropic effects in the mouse. Genet Res. 1966;8(3):295-309. 
10. Pantelouris EM. Absence of thymus in a mouse mutant. Nature. 1968; 217(5126):370-1.

11. Wortis HH, Nehlsen S, Owen JJ. Abnormal development of the thymus in "nude" mice. J Exp Med. 1971;134(3):681-92.

12. Kaestner KH, Knochel W, Martinez DE. Unified nomenclature for the winged helix/forkhead transcription factors. Genes Dev. 2000;14(2):142-6.

13. Amorosi S, D'Armiento M, Calcagno G, Russo I, Adriani M, Christiano AM, et al. FOXN1 homozygous mutation associated with anencephaly and severe neural tube defect in human athymic Nude/SCID fetus. Clin Genet. 2008;73(4):380-4.

14. Amorosi S, Vigliano I, Del Giudice E, Panico L, Maruotti GM, Fusco A, et al. Brain alteration in a Nude/SCID fetus carrying FOXN1 homozygous mutation. J Neurol Sci. 2010;298(1-2):121-3.

15. Palamaro L, Romano R, Fusco A, Giardino G, Gallo V, Pignata C. FOXN1 in organ development and human diseases. Int Rev Immunol. 2014;33(2):83-93.

16. Bleul CC, Corbeaux T, Reuter A, Fisch P, Monting JS, Boehm T. Formation of a functional thymus initiated by a postnatal epithelial progenitor cell. Nature. 2006;441(7096):992-6.

17. Meier N, Dear TN, Boehm T. Whn and $\mathrm{mHa} 3$ are components of the genetic hierarchy controlling hair follicle differentiation. Mech Dev. 1999;89(1-2): 215-21.

18. Schlake T. The nude gene and the skin. Exp Dermatol. 2001;10(5):293-304.

19. Mecklenburg L, Paus R, Halata Z, Bechtold LS, Fleckman P, Sundberg JP. FOXN1 is critical for onycholemmal terminal differentiation in nude (Foxn1) mice. J Invest Dermatol. 2004;123(6):1001-11.

20. Tasher D, Dalal I. The genetic basis of severe combined immunodeficiency and its variants. Appl Clin Genet. 2012;5:67-80.

21. Pignata C, Fusco A, Amorosi S. Human clinical phenotype associated with FOXN1 mutations. Adv Exp Med Biol. 2009;665:195-206.

22. Gennery A, Cant A. Diagnosis of severe combined immunodeficiency. J Clin Pathol. 2001;54(3):191-5.

23. Markert ML, Marques JG, Neven B, Devlin BH, McCarthy EA, Chinn IK, et al. First use of thymus transplantation therapy for FOXN1 deficiency (nude/ SCID): a report of 2 cases. Blood. 2011;117(2):688-96.

24. Romano R, Palamaro L, Fusco A, Giardino G, Gallo V, Del Vecchio L, et al. FOXN1: A Master Regulator Gene of Thymic Epithelial Development Program. Front Immunol. 2013;4:187.

25. Adriani M, Martinez-Mir A, Fusco F, Busiello R, Frank J, Telese S, et al. Ancestral founder mutation of the nude (FOXN1) gene in congenital severe combined immunodeficiency associated with alopecia in southern Italy population. Ann Hum Genet. 2004;68(Pt 3):265-8.

26. Chou J, Massaad MJ, Wakim RH, Bainter W, Dbaibo G, Geha RS. A novel mutation in FOXN1 resulting in SCID: a case report and literature review. Clin Immunol. 2014;155(1):30-2.

27. Levy E, Neven B, Entz-Werle N, Cribier B, Lipsker D. Post-thymus transplant vitiligo in a child with Foxn1 deficiency. Ann Dermatol Venereol. 2012;139(6-7):468-71.

28. Griffith LM, Cowan MJ, Notarangelo LD, Puck JM, Buckley RH, Candotti F, et al. Improving cellular therapy for primary immune deficiency diseases: recognition, diagnosis, and management. J Allergy Clin Immunol. 2009; 124(6):1152-60. e12.

29. Lehman H, Hernandez-Trujillo V, Ballow M. Diagnosing primary immunodeficiency: a practical approach for the non-immunologist. Curr Med Res Opin. 2015;31(4):697-706.

30. Pignata C, Gaetaniello L, Masci AM, Frank J, Christiano A, Matrecano E, et al. Human equivalent of the mouse Nude/SCID phenotype: long-term evaluation of immunologic reconstitution after bone marrow transplantation. Blood. 2001;97(4):880-5.

31. Villa A, Notarangelo LD, Roifman CM. Omenn syndrome: inflammation in leaky severe combined immunodeficiency. J Allergy Clin Immunol. 2008; 122(6):1082-6.

32. Auricchio L, Adriani M, Frank J, Busiello R, Christiano A, Pignata C. NAil dystrophy associated with a heterozygous mutation of the nude/scid human foxn1 (whn) gene. Arch Dermatol. 2005;141(5):647-8.

33. Lee D, Prowse DM, Brissette JL. Association between MousenudeGene Expression and the Initiation of Epithelial Terminal Differentiation. Dev Biol. 1999;208(2):362-74.

34. Brunet A, Bonni A, Zigmond MJ, Lin MZ, Juo P, Hu LS, et al. Akt Promotes Cell Survival by Phosphorylating and Inhibiting a Forkhead Transcription Factor. Cell. 1999;96(6):857-68.

35. Biggs 3rd WH, Meisenhelder J, Hunter T, Cavenee WK, Arden KC. Protein kinase B/Akt-mediated phosphorylation promotes nuclear exclusion of the winged helix transcription factor FKHR1. Proc Natl Acad Sci U S A. 1999; 96(13):7421-6.

36. Kops GJ, de Ruiter ND, De Vries-Smits AM, Powell DR, Bos JL, Burgering BM. Direct control of the Forkhead transcription factor AFX by protein kinase B. Nature. 1999;398(6728):630-4.

37. Schlake T, Schorpp M, Nehls M, Boehm T. The nude gene encodes a sequence-specific DNA binding protein with homologs in organisms that lack an anticipatory immune system. Proc Natl Acad Sci U S A. 1997;94(8): 3842-7.

38. Coffer PJ, Burgering BMT. Forkhead-box transcription factors and their role in the immune system. Nat Rev Immunol. 2004;4(11):889-99.

39. Su DM, Navarre S, Oh WJ, Condie BG, Manley NR. A domain of Foxn1 required for crosstalk-dependent thymic epithelial cell differentiation. Nat Immunol. 2003;4(11):1128-35.

40. Schüddekopf $K$, Schorpp M, Boehm T. The whn transcription factor encoded by the nude locus contains an evolutionarily conserved and functionally indispensable activation domain. Proc Natl Acad Sci U S A. 1996;93(18):9661-4.

41. Anderson $\mathrm{G}$, Jenkinson EJ. Lymphostromal interactions in thymic development and function. Nat Rev Immunol. 2001;1(1):31-40.

42. Bleul CC, Boehm T. Chemokines define distinct microenvironments in the developing thymus. Eur J Immunol. 2000;30(12):3371-9.

43. Tsukamoto N, Itoi M, Nishikawa M, Amagai T. Lack of Delta like 1 and 4 expressions in nude thymus anlages. Cell Immunol. 2005;234(2):77-80.

44. Nowell CS, Bredenkamp N, Tetélin S, Jin X, Tischner C, Vaidya H, et al. Foxn1 Regulates Lineage Progression in Cortical and Medullary Thymic Epithelial Cells But Is Dispensable for Medullary Sublineage Divergence. PLoS Genet. 2011;7(11):e1002348

45. Chen L, Xiao S, Manley NR. Foxn1 is required to maintain the postnatal thymic microenvironment in a dosage-sensitive manner. Blood. 2009:113(3):567-74.

46. Janes SM, Ofstad TA, Campbell DH, Watt FM, Prowse DM. Transient activation of FOXN1 in keratinocytes induces a transcriptional programme that promotes terminal differentiation: contrasting roles of FOXN1 and Akt. J Cell Sci. 2004;117(18):4157-68.

47. Li J, Baxter RM, Weiner L, Goetinck PF, Calautti E, Brissette JL. Foxn1 promotes keratinocyte differentiation by regulating the activity of protein kinase C. Differentiation. 2007;75(8):694-701.

48. D'Assante R, Fusco A, Palamaro L, Giardino G, Gallo V, Cirillo E, et al. Unraveling the Link Between Ectodermal Disorders and Primary Immunodeficiencies. Int Rev Immunol. 2016;35(1):25-38.

49. Picard C, Al-Herz W, Bousfiha A, Casanova JL, Chatila T, Conley ME, et al. Primary Immunodeficiency Diseases: an Update on the Classification from the International Union of Immunological Societies Expert Committee for Primary Immunodeficiency 2015. J Clin Immunol. 2015;35(8):696-726.

50. Gaspar HB, Hammarstrom L, Mahlaoui N, Borte M, Borte S. The case for mandatory newborn screening for severe combined immunodeficiency (SCID). J Clin Immunol. 2014;34(4):393-7.

51. van der Spek J, Groenwold RH, van der Burg M, van Montfrans JM. TREC Based Newborn Screening for Severe Combined Immunodeficiency Disease: A Systematic Review. J Clin Immunol. 2015;35(4):416-30.

52. Kwan A, Puck JM. History and current status of newborn screening for severe combined immunodeficiency. Semin Perinatol. 2015;39(3):194-205.

53. Chan K, Puck JM. Development of population-based newborn screening for severe combined immunodeficiency. J Allergy Clin Immunol. 2005;115(2):391-8.

54. Puck JM. Laboratory technology for population-based screening for severe combined immunodeficiency in neonates: the winner is T-cell receptor excision circles. J Allergy Clin Immunol. 2012;129(3):607-16.

55. Kwan A, Church JA, Cowan MJ, Agarwal R, Kapoor N, Kohn DB, et al. Newborn screening for severe combined immunodeficiency and T-cell lymphopenia in California: results of the first 2 years. J Allergy Clin Immunol. 2013;132(1):140-50.

56. Brown L, Xu-Bayford J, Allwood Z, Slatter M, Cant A, Davies EG, et al. Neonatal diagnosis of severe combined immunodeficiency leads to significantly improved survival outcome: the case for newborn screening. Blood. 2011;117(11):3243-6.

57. Ghosh S, Krux F, Binder V, Gombert M, Niehues T, Feyen O, et al. Array-based sequence capture and next-generation sequencing for the identification of primary immunodeficiencies. Scand J Immunol. 2012;75(3):350-4.

58. Nijman IJ, van Montfrans JM, Hoogstraat M, Boes ML, van de Corput L, Renner ED, et al. Targeted next-generation sequencing: a novel diagnostic tool for primary immunodeficiencies. J Allergy Clin Immunol. 2014;133(2): 529-34. 
59. Moens LN, Falk-Sorqvist E, Asplund AC, Bernatowska E, Smith Cl, Nilsson M Diagnostics of primary immunodeficiency diseases: a sequencing capture approach. PLoS One. 2014;9(12):e114901.

60. Al-Mousa H, Abouelhoda M, Monies DM, Al-Tassan N, Al-Ghonaium A, Al-Saud B, et al. Unbiased targeted next-generation sequencing molecular approach for primary immunodeficiency diseases. J Allergy Clin Immunol. 2016;137(6):1780-7.

61. Yu H, Zhang WW, Stray-Pedersen A, Hanson IC, Forbes LR, de la Morena MT, et al. Rapid molecular diagnostics of severe primary immunodeficiency determined by using targeted next-generation sequencing. J Allergy Clin Immunol. 2016;138(4):1142-51.e2.

62. Walkovich $\mathrm{K}$, Connelly JA. Primary immunodeficiency in the neonate: Early diagnosis and management. Semin Fetal Neonatal Med. 2016;21(1):35-43.

63. Albuquerque AS, Marques JG, Silva SL, Ligeiro D, Devlin BH, Dutrieux J, et al. Human FOXN1-deficiency is associated with alphabeta double-negative and FoxP3+ T-cell expansions that are distinctly modulated upon thymic transplantation. PLoS One. 2012;7(5):e37042.

64. Rivers L, Gaspar HB. Severe combined immunodeficiency: recent developments and guidance on clinical management. Arch Dis Child. 2015;100(7):667-72.

65. Claudio Pignata AFaSA. Human Clinical Phenotype Associated with FOXN1 Mutations. Forkhead Transcription Factors: Vital Elements in Biology and Medicine. New York: Plenum Press; 2009. p. 665.

66. Wieacker $P$, Steinhard J. The prenatal diagnosis of genetic diseases. Dtsch Arztebl Int. 2010;107(48):857-62.

67. Gennery AR, Slatter MA, Grandin L, Taupin P, Cant AJ, Veys P, et al. Transplantation of hematopoietic stem cells and long-term survival for primary immunodeficiencies in Europe: entering a new century, do we do better? J Allergy Clin Immunol. 2010;126(3):602-10 e1-11.

68. Ruhl H, Bein G, Sachs UJ. Transfusion-associated graft-versus-host disease. Transfus Med Rev. 2009;23(1):62-71

69. Davies EG. Immunodeficiency in DiGeorge Syndrome and Options for Treating Cases with Complete Athymia. Front Immunol. 2013;4:322.

70. Janda A, Sedlacek P, Honig M, Friedrich W, Champagne M, Matsumoto T, et al. Multicenter survey on the outcome of transplantation of hematopoietic cells in patients with the complete form of DiGeorge anomaly. Blood. 2010;116(13):2229-36.

71. Markert ML, Devlin BH, Chinn IK, McCarthy EA. Thymus transplantation in complete DiGeorge anomaly. Immunol Res. 2009;44(1-3):61-70.

72. McGhee SA, Lloret MG, Stiehm ER. Immunologic reconstitution in $22 \mathrm{a}$ deletion (DiGeorge) syndrome. Immunol Res. 2009;45(1):37-45.

73. Markert ML, Devlin BH, Alexieff MJ, Li J, McCarthy EA, Gupton SE, et al. Review of 54 patients with complete DiGeorge anomaly enrolled in protocols for thymus transplantation: outcome of 44 consecutive transplants. Blood. 2007;109(10):4539-47.

74. Ip W, Zhan H, Gilmour KC, Davies EG, Qasim W. 22q11.2 deletion syndrome with life-threatening adenovirus infection. J Pediatr. 2013;163(3):908-10.

75. Markert ML, Devlin BH, Chinn IK, McCarthy EA, Li YJ. Factors affecting success of thymus transplantation for complete DiGeorge anomaly. Am J Transplant. 2008;8(8):1729-36.

76. Sun X, Xu J, Lu H, Liu W, Miao Z, Sui X, et al. Directed differentiation of human embryonic stem cells into thymic epithelial progenitor-like cells reconstitutes the thymic microenvironment in vivo. Cell Stem Cell. 2013; 13(2):230-6

77. Bredenkamp N, Ulyanchenko S, O'Neill KE, Manley NR, Vaidya HJ, Blackburn CC. An organized and functional thymus generated from FOXN1-reprogrammed fibroblasts. Nat Cell Biol. 2014;16(9):902-8.

78. Okabe M, Ito S, Nishio N, Tanaka Y, Isobe K. Thymic Epithelial Cells Induced from Pluripotent Stem Cells by a Three-Dimensional Spheroid Culture System Regenerates Functional T Cells in Nude Mice. Cell Reprogram. 2015;17(5):368-75

79. Bredenkamp N, Jin X, Liu D, O'Neill KE, Manley NR, Blackburn CC. Construction of a functional thymic microenvironment from pluripotent stem cells for the induction of central tolerance. Regen Med. 2015;10(3): 317-29

80. Giliani S, Mori L, de Saint BG, Le Deist F, Rodriguez-Perez C, Forino C, et al. Interleukin-7 receptor alpha (IL-7Ralpha) deficiency: cellular and molecular bases. Analysis of clinical, immunological, and molecular features in 16 novel patients. Immunol Rev. 2005;203:110-26.

81. Puel A, Ziegler SF, Buckley RH, Leonard WJ. Defective IL7R expression in $\mathrm{T}(-) \mathrm{B}(+) \mathrm{NK}(+)$ severe combined immunodeficiency. Nat Genet. 1998;20(4):394-7.
82. Shiow LR, Paris K, Akana MC, Cyster JG, Sorensen RU, Puck JM. Severe combined immunodeficiency (SCID) and attention deficit hyperactivity disorder (ADHD) associated with a Coronin-1A mutation and a chromosome 16p11.2 deletion. Clin Immunol (Orlando, Fla). 2009; 131(1):24-30

83. Shiow LR, Roadcap DW, Paris K, Watson SR, Grigorova IL, Lebet T, et al. The actin regulator coronin $1 \mathrm{~A}$ is mutant in a thymic egress-deficient mouse strain and in a patient with severe combined immunodeficiency. Nat Immunol. 2008:9(11):1307-15.

84. Kung C, Pingel JT, Heikinheimo M, Klemola T, Varkila K, Yoo LI, et al. Mutations in the tyrosine phosphatase CD45 gene in a child with severe combined immunodeficiency disease. Nat Med. 2000;6(3):343-5.

85. Tchilian EZ, Wallace DL, Wells RS, Flower DR, Morgan G, Beverley PC. A deletion in the gene encoding the CD45 antigen in a patient with SCID. Immunol. 2001;166(2):1308-13.

86. Dadi HK, Simon AJ, Roifman CM. Effect of CD3delta deficiency on maturation of alpha/beta and gamma/delta T-cell lineages in severe combined immunodeficiency. N Engl J Med. 2003;349(19):1821-8.

87. Roifman CM. Studies of patients' thymi aid in the discovery and characterization of immunodeficiency in humans. Immunol Rev. 2005;203:143-55.

88. de Saint BG, Geissmann F, Flori E, Uring-Lambert B, Soudais C, CavazzanaCalvo $M$, et al. Severe combined immunodeficiency caused by deficiency in either the delta or the epsilon subunit of CD3. J Clin Invest. 2004;114(10): $1512-7$

89. Roberts $\mathrm{J}$, Lauritsen JP, Cooney M, Parrott RE, Sajaroff EO, Win CM, et al. $\mathrm{T}-\mathrm{B}+\mathrm{NK}+$ severe combined immunodeficiency caused by complete deficiency of the CD3zeta subunit of the T-cell antigen receptor complex. Blood. 2007;109(8):3198-206.

90. Masternak K, Barras E, Zufferey M, Conrad B, Corthals G, Aebersold R, et al. A gene encoding a novel RFX-associated transactivator is mutated in the majority of MHC class II deficiency patients. Nat Genet. 1998;20(3):273-7.

91. Ouederni M, Vincent QB, Frange P, Touzot F, Scerra S, Bejaoui M, et al. Major histocompatibility complex class $\|$ expression deficiency caused by a RFXANK founder mutation: a survey of 35 patients. Blood. 2011;118(19): 5108-18.

92. Steimle V, Durand B, Barras E, Zufferey M, Hadam MR, Mach B, et al. A novel DNA-binding regulatory factor is mutated in primary $\mathrm{MHC}$ class II deficiency (bare lymphocyte syndrome). Genes Dev. 1995;9(9):1021-32.

93. Steimle V, Otten LA, Zufferey M, Mach B. Complementation cloning of an MHC class II transactivator mutated in hereditary MHC class II deficiency (or bare lymphocyte syndrome). Cell. 1993;75(1):135-46.

94. Li FY, Chaigne-Delalande B, Su H, Uzel G, Matthews H, Lenardo MJ. XMEN disease: a new primary immunodeficiency affecting $\mathrm{Mg} 2+$ regulation of immunity against Epstein-Barr virus. Blood. 2014;123(14):2148-52.

95. Goldman FD, Ballas ZK, Schutte BC, Kemp J, Hollenback C, Noraz N, et al. Defective expression of p56lck in an infant with severe combined immunodeficiency. J Clin Investig. 1998;102(2):421-9.

96. Giliani S, Bonfim C, de Saint BG, Lanzi G, Brousse N, Koliski A, et al. Omenn syndrome in an infant with IL7RA gene mutation. J Pediatr. 2006;148(2): 272-4.

97. Gennery AR, Slatter MA, Rice J, Hoefsloot LH, Barge D, McLean-Tooke A, et al. Mutations in CHD7 in patients with CHARGE syndrome cause T-B + natural killer cell + severe combined immune deficiency and may cause Omenn-like syndrome. Clin Exp Immunol. 2008;153(1):75-80.

98. Roifman CM, Gu Y, Cohen A. Mutations in the RNA component of RNase mitochondrial RNA processing might cause Omenn syndrome. J Allergy Clin Immunol. 2006:117(4):897-903.

99. Vu QV, Wada T, Toma T, Tajima H, Maeda M, Tanaka R, et al. Clinical and immunophenotypic features of atypical complete DiGeorge syndrome. Pediatr Int. 2013;55(1):2-6.

100. Markert ML, Alexieff MJ, Li J, Sarzotti M, Ozaki DA, Devlin BH, et al. Complete DiGeorge syndrome: development of rash, lymphadenopathy, and oligoclonal T cells in 5 cases. J Allergy Clin Immunol. 2004;113(4):734-41.

101. McLean-Tooke A, Spickett GP, Gennery AR. Immunodeficiency and autoimmunity in 22q11.2 deletion syndrome. Scand J Immunol. 2007; 66(1):1-7.

102. Zentner GE, Layman WS, Martin DM, Scacheri PC. Molecular and phenotypic aspects of CHD7 mutation in CHARGE syndrome. Am J Med Genet A. 2010; 152a(3):674-86.

103. Writzl K, Cale CM, Pierce CM, Wilson LC, Hennekam RC. Immunological abnormalities in CHARGE syndrome. Eur J Med Genet. 2007;50(5):338-45. 
104. Fernandez Garcia MS, Teruya-Feldstein J. The diagnosis and treatment of dyskeratosis congenita: a review. J Blood Med. 2014;5:157-67.

105. Jyonouchi S, Forbes L, Ruchelli E, Sullivan KE. Dyskeratosis congenita: a combined immunodeficiency with broad clinical spectrum-a single-center pediatric experience. Pediatr Allergy Immunol. 2011;22(3):313-9.

106. Lee BW, Yap HK, Quah TC, Chong A, Seah CC. T cell immunodeficiency in dyskeratosis congenita. Arch Dis Child. 1992;67(4):524-6.

107. Ortega JA, Swanson VL, Landing BH, Hammond GD. Congenital dyskeratosis. Zinsser-Engman-Cole syndrome with thymic dysplasia and aplastic anemia. Am J Dis Child. 1972;124(5):701-4.

Submit your next manuscript to BioMed Central and we will help you at every step:

- We accept pre-submission inquiries

- Our selector tool helps you to find the most relevant journal

- We provide round the clock customer support

- Convenient online submission

- Thorough peer review

- Inclusion in PubMed and all major indexing services

- Maximum visibility for your research

Submit your manuscript at www.biomedcentral.com/submit 